\title{
Remove (Boron) from Irrigation Water by Using Duckweeds (Spirodela polyrhiza)
}

\section{Zohuir Al Balawna ${ }^{*}$, Ala Al Khateeb ${ }^{2}$, Othman Saleh$^{2}$, Mohammad Al Hadeedi ${ }^{2}$, Mohammad Enemat ${ }^{2}$ and Notaya Ittichinbanchon}

${ }^{1}$ Head of Lab Division, Jordan Valley Authority Labs, Dair Ulla, Jordan

${ }^{2}$ Lab Technician, Jordan Valley Authority Labs, Dair Ulla, Jordan

*Corresponding Author: Zohuir Al Balawna, Head of Lab Division, Jordan Valley Authority Labs, Dair Ulla, Jordan.

E-mail: Zohuire_Albalawna@mwi.gov.jo

Received: October 11, 2019; Published: November 15, 2019

DOI: 10.31080/ASAG.2019.03.0723

\section{Abstract}

The objectives of this study were to analyses Boron in growth media contain boron concentration $1.5 \mathrm{ppm}, 1.5 \mathrm{ppm}$ and $2.5 \mathrm{ppm}$ which covered by duckweeds (Spirodela polyrhiza) and other media contain only boron standard $0.5 \mathrm{ppm}, 2.5 \mathrm{ppm}$ and $1.5 \mathrm{ppm}$ without duckweed.

All Growth media were analyzed by using spectrophotometer technique at wave length $420 \mathrm{~nm}$ by taking different samples of growth media contain boron only, and other growth media contain boron with duckweeds (Spirodela polyrhiza).

We show in this study, Boron is decrease in first media media which contain duckweeds (Spirodela polyrhiza) by the time from 2.5 ppm to 1.55 ppm, second media media Boron is decrease from $1.5 \mathrm{ppm}$ to $1.04 \mathrm{ppm}$ third media from $0.50 \mathrm{ppm}$ to $0.27 \mathrm{ppm}$.

Keywords: Boron; Spirodela polyrhiza; Duckweed

\section{Introduction}

Jordan faces significant challenges in water sources where it became one of the poorest countries in the world in water, and the most prominent of these challenges is the inability of the available water resources to meet the growing water demand. Jordan's per capita share of water is one of the lowest ratios in the world; it decreased over the last several years to reach less than $100 \mathrm{~m}^{3}$.

The demand for water is increasing year after year. In contrast, water resources are deteriorating continuously in terms of both quality and quantity. The ratio of fresh water used in agriculture is decreasing in each day against the increasing demands of the other sectors. For sustainable agricultural production, low quality waters should also be used in agricultural irrigations. Turkey is quite rich in boron reservoirs. Ground and surface water resources around these reservoirs are contaminated with boron compounds. Use of these sources is a highly significant issue for efficient use of limited water resources.

Boron uptake by plants is controlled by the boron level in soil solution rather than the total boron content in soil. Boron uptake is a passive (non-metabolic) process. It moves with water in plant's tissues and accumulates in the leaves; therefore, Boron uptake and accumulation are directly dependent on the rate of transpiration.

The highest naturally occurring concentrations of soil B are in soils derived from marine evaporites and marine argillaceous sediment. In addition, various anthropogenic sources of excess B may increase soil B to levels toxic for plants. The most important source is irrigation water, but others include wastes from surface mining, fly ash, and industrial chemicals.
Lemnoideae is a subfamily of flowering aquatic plants, known as duckweeds, water lentils, or water lenses. They float on or just beneath the surface of still or slow-moving bodies of fresh water and wetlands. Also known as "bayroot", they arose from within the arum or aroid family (Araceae), so often are classified as the subfamily Lemnoideae within the family Araceae. Other classifications, particularly those created prior to the end of the $20^{\text {th }}$ century, place them as a separate family.

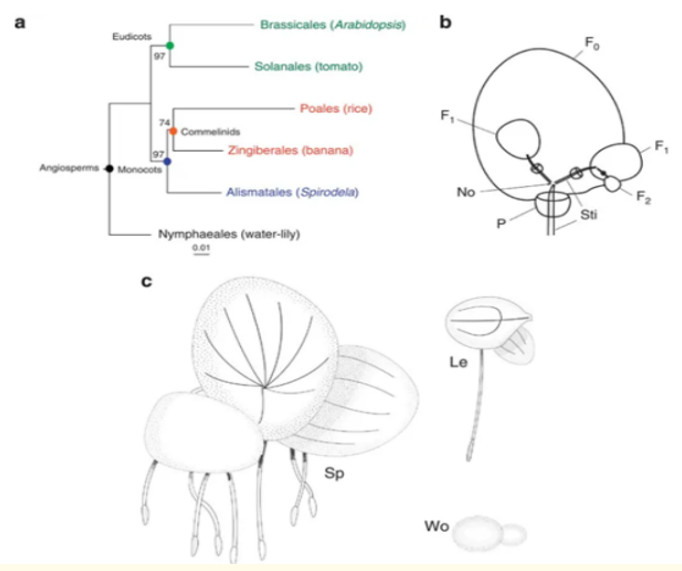

Figure 1

\section{Methodology}

Sample collection

Collection duckweeds (Spirodela polyrhiza) from lake in farm located in Jordan valley with demand area 25 and farm unit 189 and let it grow in beaker 1 liter in Jordan valley laboratories and collect the sample daily up to 5 days as in table 1 . 


\begin{tabular}{|c|c|c|c|c|c|c|}
\hline \multirow[t]{2}{*}{ Period time } & \multicolumn{2}{|c|}{ Growth media 2.5 ppm } & \multicolumn{2}{|c|}{ Growth media 1.5 ppm } & \multicolumn{2}{|c|}{ Growth media 1.5 ppm } \\
\hline & No duckweeds & With duckweeds & No duckweeds & With duckweeds & No duckweeds & With duckweeds \\
\hline 1 day & 3 sample & 3 sample & 3 sample & 3 sample & 3 sample & 3 sample \\
\hline 2 day & 3 sample & 3 sample & 3 sample & 3 sample & 3 sample & 3 sample \\
\hline 3 day & 3 sample & 3 sample & 3 sample & 3 sample & 3 sample & 3 sample \\
\hline 4 day & 3 sample & 3 sample & 3 sample & 3 sample & 3 sample & 3 sample \\
\hline 5 day & 3 sample & 3 sample & 3 sample & 3 sample & 3 sample & 3 sample \\
\hline
\end{tabular}

Table 1: Growth medias.

\section{Preparation of samples}

Taken $3 \times 10 \mathrm{ml}$ from every growth media through the time then filtered (using Whatman 15 filter paper),

All samples were immediately analyzed within $1 \mathrm{hr}$ after sample preparation.

\section{Method of analysis}

Reading samples by using method: Azomethine $\mathrm{H}$ colorimetric method for determining dissolved boron in water by spectrophotometer type perkinelmer at $420 \mathrm{~nm}$.

\section{Digestion samples}

The sample duckweeds (Spirodela polyrhiza) tissues was digested by using wet digestion method, one gram of sample taken into keddahs flask having the $1000 \mathrm{~cm}^{3}$ capacity and the sample was digestion in 3:1 ratio of $\mathrm{HCl}$ and $\mathrm{HNO}_{3}$ and leave for a whole day inside a fume hood. The mixture heated for $40^{\circ} \mathrm{C}$ for more than half hour, the heat was increased up to $100^{\circ} \mathrm{C}$ and heating continued till the solution become clear, and the white fumes disappeared indicates the completion of the digestion process.

The digestion solution diluted with distilled water and boiled about 15 minutes. The solution was cooled, and filter using Whatman filter paper and filled till the mark of keddahs flask using distilled water. The digested solution transferred into a polyethylene bottle for further analysis of heavy metal concentration using atomic absorption [1-17].

\section{Results and Discussion}

Boron concentration of growth media (1), growth media (2) and growth media (3) in table 2,3 and 4.

Which analysis by using spectrophotometer at $420 \mathrm{~nm}$, samples collected from medias which prepared in laboratories as show in table 1.

- In media (1), boron is absorbed by duckweed, so it decreases from $2.5 \mathrm{ppm}$ to $1.25 \mathrm{ppm}$ after 5 days.

- In media (2) boron is absorbed by duckweed so it decreases from $1.5 \mathrm{ppm}$ to $0.81 \mathrm{ppm}$ after 5 days.

- In media (3) boron is absorbed by duckweed so it decreases from $0.50 \mathrm{ppm}$ to $0.27 \mathrm{ppm}$ after 5 days.
Analysis the Tissues of duckweeds (Spirodela polyrhiza) show increasing in boron.

- Boron concentration in duckweeds (Spirodela polyrhiza) tissues for media (1) was $10.8 \mathrm{ppm}$.

- Boron concentration in duckweeds (Spirodela polyrhiza) tissues for media (2) was $5.80 \mathrm{ppm}$.

- Boron concentration in duckweeds (Spirodela polyrhiza) tissues for media (3) was $2.70 \mathrm{ppm}$.

\begin{tabular}{|l|c|c|}
\hline Period time & \multicolumn{2}{|c|}{ B (ppm) level } \\
\hline & No duckweeds & With duckweeds \\
\hline 1 day & 2.54 & 2.44 \\
\hline 2 day & 2.51 & 2.32 \\
\hline 3 day & 2.45 & 2.1 \\
\hline 4 day & 2.46 & 1.81 \\
\hline 5 day & 2.42 & 1.25 \\
\hline
\end{tabular}

Table 2: Boron concentration in media (1). 2.5 ppm Boron.

\begin{tabular}{|l|l|l|}
\hline Period time & \multicolumn{2}{|c|}{ B (ppm) level } \\
\hline & No duckweeds & With duckweeds \\
\hline 1 day & 1.55 & 1.42 \\
\hline 2 day & 1.52 & 1.34 \\
\hline 3 day & 1.52 & 1.25 \\
\hline 4 day & 1.49 & 1.13 \\
\hline 5 day & 1.47 & 0.81 \\
\hline
\end{tabular}

Table 3: Boron concentration in media (2)

1.5 ppm Boron.

\begin{tabular}{|l|c|c|}
\hline Period time & \multicolumn{2}{|c|}{ B (ppm) level } \\
\hline & No duckweeds & With duckweeds \\
\hline 1 day & 0.51 & 0.47 \\
\hline 2 day & 0.5 & 0.42 \\
\hline 3 day & 0.49 & 0.38 \\
\hline 4 day & 0.47 & 0.32 \\
\hline 5 day & 0.46 & 0.27 \\
\hline
\end{tabular}

Table 4: Boron concentration in media (3). $0.50 \mathrm{ppm}$ Boron. 


\section{Conclusions}

The study shows decreasing in boron level in growth media and plant increase in plant tissues of duckweeds (Spirodela polyrhiza) by using spectrophotometer at wavelength $420 \mathrm{~nm}$.

The higher concentration of boron in irrigation water is became toxicity for most of plant cover irrigation water b y using duckweeds (Spirodela polyrhiza) to remove boron from water and became safe to irrigate and safe to plant health.

\section{Bibliography}

1. M Azizur Rahman., et al. "Arsenic accumulation in duckweed (Spirodela polyrhiza L.): A good option for phytoremediation". Chemosphere 69 (2007): 493-499.

2. RishiKesh Upadhyay and Sanjib Kumar Panda. "Zinc reduces copper toxicity induced oxidative stress by promoting antioxidant defense in freshly grown aquatic duckweed Spirodela polyrhiza L". Journal of Hazardous Material 175 (2010): 10811084.

3. KJ Appenroth., et al. "Effects of nickel on the chloroplasts of the duckweeds Spirodela polyrhiza and Lemna minor and their possible use in biomonitoring and phytoremediation". Chemosphere 78 (2010): 216-223.

4. P Waranusantigul., et al. "Kinetics of basic dye (methylene blue) biosorption by giant duckweed (Spirodela polyrrhiza)". Environmental Pollution 125 (2003): 385-392.

5. TimoStadtlander., et al. "Slurry-grown duckweed (Spirodela polyrhiza) as a means to recycle nitrogen into feed for rainbow trout fry". Journal of Cleaner Production 228 (2019): 86-93.

6. Qingtao Zhang., et al. "The Growth Performance of Duckweed and Removal Rate of Nitrate and Phosphorus in Sewages with Different Processes" (2014).

7. Devaleena Chaudhuri., et al. "Cadmium Removal by Lemna minor and Spirodela polyrhiza” (2014).

8. JP Gaur., et al. "Relationship between heavy metal accumulation and toxicity in Spirodela polyrhiza (L.) Schleid. and Azolla pinnata R. Br". Aquatic Botany 49 (1994): 183-192.

9. Shanti S., et al. "Potential of Lemna polyrrhiza for removal of heavy metals". Ecological Engineering 4 (1995): 37-43.

10. Maibam Dhanaraj., et al. "Lead (II) and cadmium (II) biosorption on Spirodela polyrhiza (L.) Schleiden biomass". Journal of Environmental Chemical Engineering 1 (2013): 200-207.

11. Shanna M Davis., et al. "Toxicity of boron to the duckweed, Spirodella polyrrhiza” (2002).

12. HarunBöcük., et al. "Assessment of Lemna gibba L. (duckweed) as a potential ecological indicator for contaminated aquatic ecosystem by boron mine effluent". Ecological Indicators 29 (2013): 538-548.
13. Chunguang Liu., et al. "Boron accumulation by Lemna minor L. under salt stress" (2018).

14. R Keren and FT Bingham. "Boron in Water, Soils, and Plants". Advances in Soil Science (1958): 229-276.

15. Umesh C Gupta. "Boron toxicity and deficiency: a review". Canadian Journal of Soil Science (1985).

16. Chunming Su and Donald L Suarez. "Coordination of Adsorbed Boron: A FTIR Spectroscopic Study” (1995).

17. Cengiz Koç. "Effects on Environment and Agriculture of Geothermal Wastewater and Boron Pollution in Great Menderes Basin" (2007).

Volume 3 Issue 12 December 2019

(C) All rights are reserved by Zohuir Al Balawna., et al. 